\title{
NEW MARKET LABOR AND OBESITY: A NATION-WIDE ITALIAN CROSS-SECTIONAL STUDY
}

\section{PAMELA BARBADOR0 ${ }^{1}$, ELISA PONZI0 ${ }^{1}$, CARLOS JUAN CHIATTI ${ }^{2}$, FRANCESCO DI STANISLAO ${ }^{1}$, MARCELLO MARIO D'ERRICO ${ }^{1}$, and EMILIA PROSPERO ${ }^{1}$}

${ }^{1}$ Polytechnic University of Marche, Ancona, Italy

Department of Biomedical Science and Public Health

${ }^{2}$ Italian National Research Center on Aging, Ancona, Italy

\begin{abstract}
Objectives: To investigate the prevalence of obesity among different types of employment status in the Italian working population, and to examine associated risk factors. Material and Methods: Cross-sectional survey of 36814 people that declared to have been occupied with the same type of contract for at least 5 years was analyzed. Multivariable logistic regression models were built considering workers' sex, age, education, family body mass index (BMI) category, leisure time and occupational physical activity, weight control habits, smoking habit, use of drugs, number of working hours per week, and type of working contract. Results: After adjusting for covariates, the importance of temporary-employment was confirmed by multivariate analysis, with odds ratio $(\mathrm{OR})=1.32$ for obesity (95\% confidence interval (CI): $1.07-1.63$ ) with respect to employed persons; the association was even more important in workers occupied for more than $40 \mathrm{~h} /$ week $(\mathrm{OR}=1.69,95 \% \mathrm{CI}$ : 1.07-2.66); moreover, shiftwork was confirmed as a risk factor for obesity in workers $(\mathrm{OR}=1.06,95 \% \mathrm{CI}: 0.94-1.2)$. Dealing with different occupational group, some categories were associated with obesity; in particular, this phenomenon involved people employed in agriculture (OR $=1.44,95 \%$ CI: $1.22-1.7)$, transportation $(\mathrm{OR}=1.53,95 \% \mathrm{CI}: 1.26-1.85)$, and public administration $(\mathrm{OR}=1.31,95 \% \mathrm{CI}$ : 1.1-1.55). Conclusions: Our analysis suggest that obesity is strongly correlated with temporary employment. Maybe the way out this pathway to obesity in the future might be working better, choosing organizational flexibility rather than fixed term. Int J Occup Med Environ Health 2016;29(6):903-914
\end{abstract}

Key words:

Obesity, Epidemiology, Work, Socioeconomic factors, Employment/statistics and numerical data, Working hours

\section{INTRODUCTION}

Given the on-going economic and financial crisis involving western countries, which affected also the characteristics of the labor market with the occurrence of temporary work, and loss of income security, there is a growing interest in linking precarious employment with adverse health outcomes [1-3]. Whereas traditional research focused predominantly on the differences between low/unskilled vs. high/skilled workers [4], more recent evidence suggests that other characteristics of the employment, such as the effort-reward imbalance [5], perceived insecurity [6] and/or prospect of permanent employment [7] represent important predictors of health status. Especially, temporary employment conditions have been reported as influencing significantly psychological health, sickness leaves, mortality and the use of healthcare resources [8-9]. The correlation between obesity, overweight and job insecurity has been controversially discussed in scientific

Received: September 30, 2014. Accepted: August 3, 2015.

Corresponding author: P. Barbadoro, Polytechnic University of Marche, Department of Biomedical Science and Public Health, via Tronto 10/A, 60126 Ancona, Italy (e-mail: igiene.ricerca@gmail.com). 
literature [9], with papers reporting little or no effect [1012], while others linking job insecurity to gain and even loss in weight [13-15]. More recent studies report a direct association between overweight and obesity and self-perceived job insecurity [16]; moreover, job strain was reported to be associated with obesity in previous cross-sectional studies [17], and job schedule including shift-work has been recently associated with obesity [18]. However, the implementation of organizational intervention at work has given uncertain results [19], revealing that there is still room to improvement in our knowledge of the interaction between working conditions and obesity. The main aim of this study was to describe the prevalence and risk factors of obesity among workers with different type of employment status, including those with temporary contracts, in a nationwide sample of the Italian working population.

\section{MATERIAL AND METHODS}

The study population consisted of participants of the national health survey "Health and use of health care services" carried out by the Italian National Institute of Statistics (ISTAT) on a 5 year basis, which aims at investigating a variety of aspects associated with the health status of the population, e.g., the prevalence of chronic diseases, the lifestyles and the patterns of health care use [20]. A description of sampling strategy has been summarized elsewhere [21]. Each survey participant completed a self-administered questionnaire, and had a face-to-face interview with ISTAT data collectors. The last edition, carried out between December 2004 and September 2005, gathered data on 50474 families and 128040 individuals, representative in terms of age and gender of the Italian population. For the present study, a selection of people aged 15-64 was considered as a representative of the occupationally active Italian population. Subsequently, those declaring to have been working during the previous week, or to have not worked just for a temporary reason, were included in the study. Moreover, selected participants declared to have been in the same working position at least for 5 years at the time of the survey.

\section{Socio-demographic and health data and lifestyle information}

Body mass index (BMI) was calculated from self-reported body weight and height specified during the survey.

According to the World Health Organization (WHO) definition, persons with a BMI $18.5-24.9 \mathrm{~kg} / \mathrm{m}^{2}$ were considered to have a healthy weight; those with a BMI 25$29.9 \mathrm{~kg} / \mathrm{m}^{2}$ were classified as overweight; and those with a BMI $\geq 30 \mathrm{~kg} / \mathrm{m}^{2}$ were categorized as obese [22].

Household mean BMI category was calculated from the respective data on members of the family of the participant worker, excluding the worker himself, and classified according to the WHO as above [22]. Data was also collected on gender, age, education (classified as low if workers had graduated only from a primary and/or secondary school, and high in the remaining cases), smoking habits (smoker vs. non-smoker or former smoker), presence of chronic conditions/drugs possibly attributable to overweight/obesity (such as chronic thyroiditis, asthma, hypertension, anxiety or depression). Leisure time physical activity (LTPA) was assessed by self-report among all participants using an adapted version of the International Physical Activity Questionnaire (IPAQ) [23]; according to the IPAQ methodology, LTPA has been categorized into low, moderate and high. Data on dietary habits (participants practicing weight control, or weight loss diet) were also considered.

\section{Occupational data}

All respondents were asked about their occupation, with particular interest in the type of contract (classified as: entrepreneur (with at least 1 employee), freelance (usually professionals), employee (permanent contract), artisan, and temporary employee).

A temporary employee was considered as a worker being occupied in "at term" work, independently from 
the duration of the contract and the nature of occupation. Number of working hours a week was categorized as follows: < 35 h, 35-39 h, 40-49 h, $\geq 50$ h; long-worker has been defined as a person with $>40 \mathrm{~h}$ of work a week. According to the Italian National Institute of Statistics, industrial and occupational classification of jobs included the following categories: agriculture, energy, manufacturing, building, commerce, bar and catering, transportation, financial services, real estate, public administration, teaching, healthcare, and other services. The evaluation of occupational physical activity (OPA) has been assessed by the following question: "Your occupation is predominantly characterized by a physical activity which is: a) scarce, the majority of time is spent in the sitting position; b) moderate, majority of time is spent standing or walking; c) hard, until sweating."

Multivariable logistic regression models were built in order to assess variables associated with obesity in Italian workers. Explanatory variables that were associated with the outcome at a significance of $\leq 0.2$ in bivariate analysis, were included as independent variables to adjust for the indirect effects of other variables.

Association between the characteristics and obesity was expressed as odds ratios (OR) and 95\% confidence intervals (CI). In particular, the 1st model included the following variables: workers sex $(1=$ male, $2=$ female $)$; age class ( $1=15-44$ years, $2=45-54$ years, $3=>55$ years $)$; family BMI category $(1=$ normal or underweight, $2=$ overweight, 3 = obese); level of LTPA ( $1=$ low, 2 = moderate, $3=$ high); dietary habits (weight loss/control diet $=1$ ); presence of chronic conditions (such as chronic thyroiditis, asthma, hypertension, anxiety or depression) was considered as a dummy $(0 ; 1)$ variable; working hours per week $(1=<35$ h, $2=35-39$ h, $3=\geq 40$ h); type of working contract $(1=$ permanent employee, $2=$ entrepreneur $($ with at least 1 employee), $3=$ freelance, $4=$ artisan, $5=$ temporary employee); being occupied in shift-work (1 = yes); level of OPA ( 1 = low, 2 = moderate, 3 = high $)$; occupational classification of jobs (as dummy variables). In the 2nd model, working category was transformed into a dummy variable, by coding new variables considering the interaction of category with a number of working hours/week exceeding 40 ( $1=\geq 40 \mathrm{~h} /$ week, $0=<40 \mathrm{~h} /$ week $)$.

Model validity was evaluated by using Hosmer and Lemeshow test and checking for collinearity. Significance level was set at $\alpha=0.05$. All analyses were conducted using the Stata version 9.0 software (Stata Corporation, Texas).

\section{RESULTS}

A total of 80661 persons were selected from the Italian multipurpose survey database in the 15-64 years old age range; while a final sample of 36814 people (aged 1864 years) reported having been occupied in the same work for at least 5 years, therefore they have been included in the analysis (Table 1). Obesity was present in $9.31 \%(\mathrm{~N}=3427)$ of workers.

Obesity was more frequent among males (11.08\%, $\mathrm{N}=2542)$ than women $(6.38 \%, \mathrm{~N}=885)$, older age was associated with obesity, with frequencies of the phenomenon increasing from $4.77 \%(\mathrm{~N}=352)$ in the $18-34$ years old, to $14.31 \%(\mathrm{~N}=738)$ in the $55-65$ years old group.

Education as a risk factor was evident at bivariate analysis, with $12.14 \%$ of frequency of obesity in less educated workers.

Poor LTPA was a risk factor for obesity (13.37\% prevalence of obesity) together with being a former smoker $(12.05 \%)$. Some of participants $(25.35 \%)$ practicing weight control were obese, and this condition was associated with the use of drugs to treat some chronic diseases such as: asthma (13.25\%), hypertension (22.53\%), depression/anxiety (13.33\%), and thyroid disease (13.99\%). Other factors associated with obesity included: overweight in the family of origin (with $13.09 \%$ of obesity in this class), workers working 36-39 h/week (10.07\%) or > 50 h/week (11.92\% prevalence of obesity), artisans $(12.13 \%)$, and sector of occupation, such as: agriculture (15\%), energy 
Table 1. Workers' obesity by selected socio-demographic characteristics and occupational group

\begin{tabular}{|c|c|c|c|}
\hline \multirow[b]{2}{*}{ Characteristic } & \multicolumn{2}{|c|}{ Respondents } & \multirow[b]{2}{*}{$\mathrm{p}$} \\
\hline & $\begin{array}{c}\text { total } \\
{[\mathrm{n}]}\end{array}$ & $\begin{array}{c}\text { obese } \\
{[\mathrm{n}(\%)]}\end{array}$ & \\
\hline Gender & & & $<0.001$ \\
\hline male & 22937 & $2542(11.08)$ & \\
\hline female & 13877 & $885(6.38)$ & \\
\hline Age & & & $<0.001$ \\
\hline $18-34$ years & 7375 & $352(4.77)$ & \\
\hline $35-54$ years & 24280 & $2337(9.63)$ & \\
\hline $55-65$ years & 5159 & $738(14.31)$ & \\
\hline Education & & & $<0.001$ \\
\hline higher & 20249 & $1416(6.99)$ & \\
\hline lower & 16565 & $2011(12.14)$ & \\
\hline Household BMI & & & $<0.001$ \\
\hline healthy weight & 20101 & $1314(8.78)$ & \\
\hline overweight & 13239 & 795 (13.09) & \\
\hline obese & 3427 & $1318(8.35)$ & \\
\hline Leisure time physical activity & & & $<0.001$ \\
\hline low & 7018 & $938(13.37)$ & \\
\hline moderate & 7825 & $764(9.76)$ & \\
\hline high & 21971 & $1725(7.85)$ & \\
\hline Smoking habit & & & $<0.001$ \\
\hline non smoker & 17334 & $1405(8.11)$ & \\
\hline former smoker & 8935 & $1077(12.05)$ & \\
\hline smoker & 10545 & $945(8.96)$ & \\
\hline \multicolumn{4}{|l|}{ Nutritional habit } \\
\hline weight control/loss program & 1128 & $286(25.35)$ & $<0.001$ \\
\hline \multicolumn{4}{|l|}{ Drugs/Chronic conditions } \\
\hline asthma & 747 & $99(13.25)$ & $<0.001$ \\
\hline hypertension & 2792 & $629(22.53)$ & $<0.001$ \\
\hline depression/anxiety & 780 & $104(13.33)$ & $<0.001$ \\
\hline hypothyroidism & 965 & 135 (13.99) & $<0.001$ \\
\hline Working time & & & $<0.001$ \\
\hline$\leq 35 \mathrm{~h} /$ week & 6530 & $500(7.66)$ & \\
\hline $36-39 \mathrm{~h} /$ week & 6922 & $617(10.07)$ & \\
\hline $40-49 \mathrm{~h} /$ week & 16741 & $1441(8.61)$ & \\
\hline$\geq 50 \mathrm{~h} /$ week & 6621 & 789 (11.92) & \\
\hline
\end{tabular}


Table 1. Workers' obesity by selected socio-demographic characteristics and occupational group - cont.

\begin{tabular}{|c|c|c|c|}
\hline \multirow[b]{2}{*}{ Characteristic } & \multicolumn{2}{|c|}{ Respondents } & \multirow[b]{2}{*}{$\mathrm{p}$} \\
\hline & $\begin{array}{c}\text { total } \\
{[\mathrm{n}]}\end{array}$ & $\begin{array}{c}\text { obese } \\
{[\mathrm{n}(\%)]}\end{array}$ & \\
\hline Type of occupation & & & $<0.001$ \\
\hline employed & 25759 & $2212(8.59)$ & \\
\hline entrepreneur & 1953 & $214(10.96)$ & \\
\hline freelance & 2066 & $169(8.18)$ & \\
\hline artisan & 5069 & $615(12.13)$ & \\
\hline temporary employed & 1967 & $120(11.03)$ & \\
\hline Sector of occupation & & & $<0.001$ \\
\hline agriculture & 2320 & $348(15.0)$ & \\
\hline energy & 349 & $32(9.17)$ & \\
\hline industry & 6958 & $569(8.18)$ & \\
\hline construction & 3127 & $321(10.27)$ & \\
\hline commerce & 4974 & $421(8.46)$ & \\
\hline bar and catering & 1096 & $87(7.94)$ & \\
\hline transportation & 1776 & $265(14.92)$ & \\
\hline financial services & 833 & $52(6.24)$ & \\
\hline real estate & 1237 & $79(6.39)$ & \\
\hline public administration & 3749 & $398(10.62)$ & \\
\hline teaching & 2851 & $212(7.44)$ & \\
\hline healthcare & 2984 & $249(8.34)$ & \\
\hline others & 4560 & $394(8.64)$ & \\
\hline Occupational physical activity & & & $<0.001$ \\
\hline low & 12622 & $1002(7.94)$ & \\
\hline moderate & 16127 & $1477(9.16)$ & \\
\hline high & 8065 & $948(11.75)$ & \\
\hline Shift work & & & $<0.001$ \\
\hline no & 20273 & $1976(8.88)$ & \\
\hline yes & 13114 & $1451(9.96)$ & \\
\hline
\end{tabular}

BMI - body mass index.

(9.17\%), industry $(8.18 \%)$, construction $(10.27 \%)$, commerce $(8.46 \%)$, bar and catering $(7.94 \%)$, transportation (14.92\%), financial service $(6.24 \%)$, real estate $(6.39 \%)$, public administration $(10.62 \%)$, teaching $(7.44 \%)$, healthcare $(8.34 \%)$ and others $(8.64 \%)$.
Logistic regression analysis (Table 2) has underlined the importance of gender in obesity; in fact, females showed $44 \%$ less risk of being obese relative to males $(\mathrm{OR}=0.56,95 \% \mathrm{CI}: 0.5-0.62)$, as well as of age with workers of 55-65 years having an $\mathrm{OR}=2.20$ 
(95\% CI: 1.91-2.54) of obesity relative to younger colleagues. The importance of low education as a risk factor for obesity was confirmed by multivariate analysis $(\mathrm{OR}=1.62,95 \% \mathrm{CI}: 1.49-1.78)$, together with that of poor LTPA (being active at moderate or high level was protective against obesity, with $\mathrm{OR}=0.81$, 95\% CI: $0.73-0.9$, and OR $=0.77,95 \%$ CI: $0.7-0.86$, respectively).

Table 2. Logistic regression analysis regarding factors associated with obesity in workers (model A) and the interaction between working time and type of work (model B)

\begin{tabular}{|c|c|c|c|c|c|c|}
\hline \multirow{2}{*}{ Variable } & \multicolumn{3}{|c|}{$\begin{array}{c}\text { Model A } \\
<40 \mathrm{~h} / \text { week }\end{array}$} & \multicolumn{3}{|c|}{$\begin{array}{c}\text { Model B } \\
\geq 40 \mathrm{~h} / \text { week }\end{array}$} \\
\hline & OR & $95 \% \mathrm{CI}$ & $\mathrm{p}$ & OR & $95 \% \mathrm{CI}$ & $\mathrm{p}$ \\
\hline \multicolumn{7}{|l|}{ Gender } \\
\hline male & 1.00 & & & & & \\
\hline female & 0.56 & $0.51-0.62$ & $<0.001$ & 0.56 & $0.50-0.62$ & $<0.001$ \\
\hline \multicolumn{7}{|l|}{ Age } \\
\hline 18-34 years & 1.00 & & & & & \\
\hline $35-54$ years & 1.85 & $1.64-2.08$ & $<0.001$ & 1.85 & $1.65-2.09$ & $<0.001$ \\
\hline $55-65$ years & 2.20 & $1.91-2.54$ & $<0.001$ & 2.21 & $1.92-2.55$ & $<0.001$ \\
\hline \multicolumn{7}{|l|}{ Education } \\
\hline higher & 1.00 & & & & & \\
\hline lower & 1.62 & $1.49-1.78$ & $<0.001$ & 1.64 & $1.50-1.79$ & $<0.001$ \\
\hline \multicolumn{7}{|l|}{ Household BMI } \\
\hline healthy weight & 1.00 & & & & & \\
\hline overweight & 1.60 & $1.45-1.77$ & $<0.001$ & 1.60 & $1.45-1.76$ & $<0.001$ \\
\hline obese & 1.19 & $1.10-1.30$ & $<0.001$ & 1.19 & $1.09-1.29$ & $<0.001$ \\
\hline \multicolumn{7}{|l|}{ Leisure time physical activity } \\
\hline low & 1.00 & & & 1.00 & & \\
\hline moderate & 0.81 & $0.73-0.90$ & $<0.001$ & 0.81 & $0.73-0.90$ & $<0.001$ \\
\hline high & 0.77 & $0.70-0.86$ & $<0.001$ & 0.77 & $0.70-0.86$ & $<0.001$ \\
\hline \multicolumn{7}{|l|}{ Smoking habit } \\
\hline smoker & 1.00 & & & 1.00 & & \\
\hline former smoker & 1.26 & $1.15-1.39$ & $<0.001$ & 1.26 & $1.15-1.39$ & $<0.001$ \\
\hline non smoker & 1.03 & $0.94-1.13$ & n.s. & 1.03 & $0.94-1.13$ & n.s. \\
\hline \multicolumn{7}{|l|}{ Nutritional habit } \\
\hline weight control/loss program & 4.47 & $3.85-5.19$ & $<0.001$ & 4.45 & $3.83-5.18$ & $<0.001$ \\
\hline \multicolumn{7}{|l|}{ Drugs/Chronic conditions } \\
\hline asthma & 1.43 & $1.14-1.79$ & $<0.001$ & 1.43 & $1.14-1.79$ & $<0.001$ \\
\hline hypertension & 2.49 & $2.25-2.77$ & $<0.001$ & 2.51 & $2.26-2.79$ & $<0.001$ \\
\hline depression/anxiety & 1.30 & $1.05-1.63$ & $<0.050$ & 1.30 & $1.04-1.62$ & $<0.050$ \\
\hline thyroid diseases & 1.73 & $1.42-2.11$ & $<0.001$ & 1.73 & $1.42-2.11$ & $<0.001$ \\
\hline
\end{tabular}


Table 2. Logistic regression analysis regarding factors associated with obesity in workers (model A) and the interaction between working time and type of work (model B) - cont.

\begin{tabular}{|c|c|c|c|c|c|c|}
\hline \multirow[t]{2}{*}{ Variable } & \multicolumn{3}{|c|}{$\begin{array}{c}\text { Model A } \\
<40 \mathrm{~h} / \text { week } \\
\end{array}$} & \multicolumn{3}{|c|}{$\begin{array}{c}\text { Model B } \\
\geq 40 \mathrm{~h} / \text { week }\end{array}$} \\
\hline & OR & $95 \% \mathrm{CI}$ & $\mathrm{p}$ & OR & $95 \% \mathrm{CI}$ & $\mathrm{p}$ \\
\hline \multicolumn{7}{|l|}{ Working time } \\
\hline$\leq 35 \mathrm{~h} /$ week & 1.00 & & & 1.00 & & \\
\hline $36-39 \mathrm{~h} /$ week & 1.14 & $0.99-1.30$ & n.s. & 1.11 & $0.97-1.27$ & n.s. \\
\hline $40-49 \mathrm{~h} /$ week & 0.96 & $0.85-1.10$ & n.s. & 0.96 & $0.85-1.08$ & n.s. \\
\hline$\geq 50 \mathrm{~h} /$ week & 1.15 & $0.95-1.38$ & n.s. & 1.29 & $1.08-1.55$ & $<0.050$ \\
\hline \multicolumn{7}{|l|}{ Type of occupation ${ }^{\mathrm{a}}$} \\
\hline employed & 0.87 & $0.68-1.30$ & n.s. & 0.87 & $0.56-1.36$ & n.s. \\
\hline entrepreneur & 1.10 & $0.92-1.31$ & n.s. & 1.13 & $0.93-1.38$ & n.s. \\
\hline freelance & 1.01 & $0.84-1.22$ & n.s. & 1.04 & $0.80-1.35$ & n.s. \\
\hline artisan & 1.10 & $0.96-1.26$ & n.s. & 1.13 & $0.98-1.31$ & n.s. \\
\hline temporary employed & 1.32 & $1.07-1.63$ & $<0.050$ & 1.69 & $1.07-2.66$ & $<0.050$ \\
\hline \multicolumn{7}{|l|}{ Occupational group } \\
\hline agriculture & 1.44 & $1.22-1.70$ & $<0.050$ & 1.14 & $0.93-1.41$ & n.s. \\
\hline energy & 0.94 & $0.64-1.39$ & n.s. & 0.75 & $0.50-1.22$ & n.s. \\
\hline industry & 0.91 & $0.79-1.05$ & n.s. & 0.71 & $0.60-0.85$ & $<0.050$ \\
\hline construction & 0.95 & $0.81-1.12$ & n.s. & 0.74 & $0.60-0.90$ & $<0.050$ \\
\hline commerce & 0.92 & $0.79-1.07$ & n.s. & 0.74 & $0.61-0.90$ & $<0.050$ \\
\hline bar and catering & 0.91 & $0.71-1.76$ & n.s. & 0.74 & $0.57-0.98$ & $<0.050$ \\
\hline transportation & 1.53 & $1.26-1.85$ & $<0.050$ & 1.30 & $1.07-1.58$ & n.s. \\
\hline financial services & 0.90 & $0.66-1.23$ & n.s. & 0.71 & $0.51-0.99$ & $<0.050$ \\
\hline real estate & 0.87 & $0.67-1.12$ & n.s. & 1.08 & $0.89-1.31$ & n.s. \\
\hline public administration & 1.31 & $1.10-1.55$ & $<0.050$ & 0.92 & $0.74-1.15$ & n.s. \\
\hline teaching & 1.17 & $0.96-1.42$ & n.s. & 1.17 & $0.97-1.43$ & n.s. \\
\hline healthcare & 1.16 & $0.96-1.41$ & n.s. & 1.12 & $0.83-1.54$ & n.s. \\
\hline others & 0.85 & $0.70-1.07$ & n.s. & 0.85 & $0.70-1.07$ & n.s. \\
\hline \multicolumn{7}{|c|}{ Occupational physical activity } \\
\hline low & 1.00 & & & 1.00 & & \\
\hline moderate & 1.01 & $0.92-1.11$ & n.s. & 1.07 & $0.97-1.17$ & n.s. \\
\hline high & 1.13 & $1.01-1.26$ & $<0.050$ & 1.15 & $1.02-1.30$ & $<0.050$ \\
\hline \multicolumn{7}{|l|}{ Shiftwork } \\
\hline no & 1.00 & & & & 1.00 & \\
\hline yes & 1.06 & $0.94-1.20$ & n.s. & 0.98 & $0.88-1.08$ & n.s. \\
\hline
\end{tabular}

${ }^{a}$ Model B includes the following categories: entrepreneur, freelance, artisan, temporary employed, persons working $\geq 40 \mathrm{~h} /$ week vs. those working $<40 \mathrm{~h} /$ week.

OR - odds ratio; CI - confidence interval; n.s. - not statistically significant.

BMI - body mass index. 
All considered medications used to treat chronic conditions were associated with obesity, thus useful in the adjusting process. As expected, former smokers were at high risk for obesity, with OR $=1.26$ (95\% CI: 1.15-1.39). Workers employed $\geq 50 \mathrm{~h}$ have shown a high risk of obesity $(\mathrm{OR}=1.29,95 \% \mathrm{CI}$ : 1.08-1.55). Moreover, temporary-employed workers showed a higher risk relative to employed $(\mathrm{OR}=1.32,95 \% \mathrm{CI}: 1.07-1.63)$; results considering the interaction between type of occupation, and number of working hours/week were similar, but highlighting the role of temporary employment, which was even more risky for workers working $>40 \mathrm{~h} /$ week $(\mathrm{OR}=1.69$, 95\% CI: 1.07-2.66) (Table 2, model B); moreover, shiftwork was confirmed as a risk factor for obesity in workers (OR $=1.06,95 \%$ CI: 0.94-1.2).

Referring to different occupational groups, some categories were associated with obesity, in particular, this phenomenon involved people employed in agriculture $(\mathrm{OR}=1.44$, 95\% CI: $1.22-1.7)$, transportation (OR $=1.53,95 \%$ CI: $1.26-$ $1.85)$, and public administration $(\mathrm{OR}=1.31,95 \% \mathrm{CI}: 1.1-$ $1.55)$; on the other hand, the inclusion of interaction between working contract and long work hours has evidenced a lower prevalence of obesity in workers occupied in industry $(\mathrm{OR}=0.71,95 \%$ CI: $0.6-0.85)$, construction $(\mathrm{OR}=0.74$, 95\% CI: $0.6-0.9)$, commerce (OR $=0.74,95 \%$ CI: $0.61-0.9)$, and bar and catering $(\mathrm{OR}=0.74,95 \% \mathrm{CI}: 0.57-0.98)$.

\section{DISCUSSION}

Our analysis in the Italian context adds to the existing knowledge, suggesting that obesity is significantly correlated with non-permanent/temporary employments.

The association remains valid even after controlling for other important covariates such as education, age, gender, family BMI category, leisure time and occupational physical activity, weight control habits, smoking habit, use of drugs. Moreover, the impact of working hours per week has been more deeply investigated, with the finding of a differential role of weekly working hours on obesity. In fact, while the interaction between working $>40 \mathrm{~h} /$ week was associated with a higher risk of obesity in temporary workers, this association was not found in entrepreneurs, freelance, artisans, and permanently employed workers, thus reinforcing the potential role of job insecurity and occupational changes during lifetime in weight gain.

The results are in line with a recent study from the literature that found significant associations between long work hours, hostile work environments, and obesity among a nationally representative sample of U.S. workers. However, in Italy, we have found a lower prevalence of obesity $(9.1 \%)$ in the working population, with respect to the USA, where $27.7 \%$ of workers are obese [24].

The relevance of such findings has also to be considered with reference to modern labor market deregulation. Today, flexible/temporary employments account for the large majority of newly created workplaces, and it is increasingly difficult for new generations of workers to find permanent occupations. According to official 2014 figures, the rate of non-permanent employments reaches $28.3 \%$ in Poland, and temporary contract rate was higher than 1 in 5 in Spain (24\%), Portugal (21.4\%) and the Netherlands (21.1\%) [25]. In Italy roughly 1 out of 7 employees works on a temporary basis [25]. This phenomenon is in contrast with the traditional, strict Employment Protection Legislation adopted in Italy, with legal and normative regulations that make hiring and firing quite difficult.

These data, in conjunction with those suggested by the growing literature on the linkage between type of job/ job insecurity and adverse health effects [26], such as that of obesity, must set an alert on the future of new generations, and the future expenditure for health care services. In fact, given the results of the above study, we may hypothesize a positive effect of the Italian employment policy, historically based on permanent occupation, on health and longevity; moreover, this hypothesis is also supported by the substantial equivalence of other known risk factors for disease and injury [27]. 
We have found significant associations between some kind of occupational sectors and obesity, independent from other covariates; in particular, workers occupied in agriculture, transportation, and in the public administration have shown an increased risk of obesity.

These findings are in line with existing evidences from the literature; in fact, according to one study, the normal weight group and the morbidly obese group differed in terms of gender, socioeconomic status and also in terms of industrial classification of jobs they served [28]. In particular, the analysis by categories of subjects has put into evidence the high frequency of obesity among transportation workers, a finding in line with a recently published study investigating obesity among professional drivers in Italy [29]. Similarly, an even higher prevalence of obesity in workers employed in public administration, was also revealed in the study by Luckhaupt et al. [24]. After adjusting for the interaction of working contract and $>40 \mathrm{~h} /$ week, however, a number of categories showed a lower risk of obesity, in particular, this phenomenon was found in workers employed in manufacturing industry, construction, financial, real estate, commerce, bar and catering services. These alternate findings seem in accordance with the observations from a recent meta-analysis concluding that the link between longer working hours and type 2 diabetes was apparent only in individuals in the low socioeconomic status groups [30] and, considering more specific findings linking working conditions with obesity, it may be especially harmful to lower-income workers [31].

Possible limitations of the study have to be considered. Studies in the economic sciences have found that obesity and overweight could influence employers decisions during the hiring process.

Persisting stereotypes describe overweight and obese persons as lazy, lacking in self-discipline and less competent [32], with absenteeism and costs attributable to that health condition [33-37]. According to this interpretation, the association found can be seen as the result of discriminating human resource policies at company level; with a negative effect of obesity on obtaining a permanent occupation. Given this potential "dual nature" of flexibility-obesity association, further longitudinal studies are required to explain the causal pathways between the 2 investigated variables. Moreover, since 1885 [38] it has been recognized that workers may have a lower morbidity and mortality compared to the general population, because relatively healthy individuals are more likely to become employed and continue being employed relative to severely ill and chronically disabled persons $[39,40]$. This phenomenon is known as the "healthy worker effect," and maybe linked to bias in epidemiological studies. Another possible limitation of the study may be linked to the lack of a direct evaluation of sleeping patterns of participants, in a context of increasing evidence of a linkage between sleeping hours and overweight/obesity [41], and the lack of information about the nutritional habits of the participants.

On the other hand, public health impact of obesity at work has to be discussed: in fact, obese subjects are known to suffer higher levels of cancer and heart disease [42], as well as to being affected from some functional limitations, including reduced flexibility, limited range of movement, and lower endurance [43]. The balance between long-term cost of unhealthy obese workers and the short-term benefit of working policies putting the workers at high risk for unhealthy conditions, should therefore be evaluated from an economic perspective.

\section{CONCLUSIONS}

Obesity and occupational injury are important concerns, afflicting millions of workers in the world; better understanding of factors that may lead to increased rates of illness and injury, including both workplace factors, as well as personal factors such as physical and mental health, will be important in helping to control the burden of obesity as an occupational disease. 
Further studies are needed to support the design of evidence-based prevention programs aimed at health promotion and weight management in the workplace.

From a health policy perspective, the European trends in increasing utilization of temporary contracts sustain the relevance of the above findings, suggesting the need of immediate action addressing these types of workers. In this sense, our study contributes to the debate on the implementation of "flexicurity policies," by suggesting that policy makers should take into consideration the health consequences of such policies when assessing costs and benefits of possible welfare reforms. The findings will also be of interest to employee advocacy groups and employer representative organizations, in order to stimulate their counterparts to implement less myopic policies. In fact, if it is generally recognized that prevention fails when there is an economic and financial crisis [44-46], decision makers should transform this apparent limitation into an opportunity to necessarily select cost-effective interventions. Maybe the way out of this pathway to obesity in the near future might be working better, choosing organizational flexibility, not fixed term.

\section{REFERENCES}

1. László KD, Pikhart H, Kopp MS, Bobak M, Pajak A, Malyutina S, et al. Job insecurity and health: A study of 16 European countries. Soc Sci Med. 2010;70(6):867-74, http://dx.doi. org/10.1016/j.socscimed.2009.11.022.

2. Bohle P, Willaby H, Quinlan M, McNamara M. Flexible work in call centres: Working hours, work-life conflict and health. Appl Ergon. 2011;42(2):219-24, http://dx.doi.org/10.1016/ j.apergo.2010.06.007.

3. McNamara M, Bohle P, Quinlan M. Precarious employment, working hours, work-life conflict and health in hotel work. Appl Ergon. 2011;42(2):225-32, http://dx.doi.org/10.1016/ j.apergo.2010.06.013.

4. Stringhini S, Dugravot A, Shipley M, Goldberg M, Zins M, Kivimäki $\mathrm{M}$, et al. Health behaviours, socioeconomic status, and mortality: Further analyses of the British Whitehall II and the French GAZEL prospective cohorts. PLoS Med. 2011;8(2):e1000419, http://dx.doi.org/10.1371/journal. pmed.1000419.

5. Inoue M, Tsurugano S, Nishikitani M, Yano E. Effort-reward imbalance and its association with health among permanent and fixed-term workers. Biopsychosoc Med. 2010;4:16, http://dx.doi.org/10.1186/1751-0759-4-16.

6. Virtanen P, Janlert U, Hammarström A. Exposure to temporary employment and job insecurity: A longitudinal study of the health effects. Occup Environ Med. 2011;68(8):570-4, http://dx.doi.org/10.1136/oem.2010.054890.

7. Kompier M, Ybema JF, Janssen J, Taris T. Employment contracts: Cross-sectional and longitudinal relations with quality of working life, health and well-being. J Occup Health. 2009;51(3):193-203, http://dx.doi.org/10.1539/joh.L8150.

8. Kivimäki M, Vahtera J, Virtanen M, Elovainio M, Pentti J, Ferrie JE. Temporary employment and risk of overall and cause-specific mortality. Am J Epidemiol. 2003;158(7):6638, http://dx.doi.org/10.1093/aje/kwg185.

9. Ferrie J, Westerlund H, Virtanen M, Vahtera J, Kivimaki M. Flexible labor markets and employee health. Scand J Work Environ Health. 2008;6:98-110.

10. Ferrie JE, Shipley MJ, Marmot MG, Stansfeld S, Davey Smith $\mathrm{G}$. The health effects of major organisational change and job insecurity. Soc Sci Med. 1998;46(2):243-54, http:// dx.doi.org/10.1016/S0277-9536(97)00158-5.

11. Pollard TM. Changes in mental well-being, blood pressure and total cholesterol levels during workplace reorganization: The impact of uncertainty. Work Stress. 2001;15:14-28, http://dx.doi.org/10.1080/02678370110064609.

12. Pelfrene E, Vlerick P, Moreau M, Mak RP, Kornitzer M, de Backer G. Perceptions of job insecurity and the impact of world market competition as health risks: Results from Belstress. J Occup Organ Psychol. 2003;76(5):411-25, http:// dx.doi.org/10.1348/096317903322591569.

13. Ferrie JE, Shipley M, Marmot MG, Stansfeld SA, Davey Smith G. An uncertain future: The health effects of threats 
to employment security in white-collar men and women. Am J Public Health. 1998;88(7):1030-6, http://dx.doi.org/ 10.2105/AJPH.88.7.1030.

14. Ferrie JE, Shipley MJ, Stansfeld SA, Marmot MG. Effects of chronic job insecurity and change in job security on self-reported health, minor psychiatric morbidity, physiological measures and health-related behaviours in British civil servants: The Whitehall II study. J Epidemiol Community Health. 2002;56(6):450-4, http://dx.doi.org/10.1136/ jech.56.6.450.

15. Bethge M, Radoschewski FM, Muller-Fahrnow W. [Job insecurity as risk for adverse health effects amongst German workers: A cohort study]. Gesundheitswesen. 2008;70(7):381-6, http://dx.doi.org/10.1055/s-0028-1082078. German.

16. Muenster E, Rueger H, Ochsmann E, Letzel S, Toschke AM. Association between overweight, obesity and self-perceived job insecurity in German employees. BMC Public Health. 2011;11:162, http://dx.doi.org/10.1186/1471-2458-11-162.

17. Overgaard D, Gamborg M, Gyntelberg F, Heitmann BL. Psychological workload and weight gain among women with and without familial obesity. Obesity (Silver Spring). 2006;14(3):458-63, http://dx.doi.org/10.1038/oby.2006.60.

18. Han K, Trinkoff AM, Storr CL, Geiger-Brown J, Johnson KL, Park S. Comparison of job stress and obesity in nurses with favorable and unfavorable work schedules. J Occup Environ Med. 2012;54(8):928-32, http://dx.doi.org/10.1097/ JOM.0b013e31825b1bfc.

19. Joyce K, Pabayo R, Critchley JA, Bambra C. Flexible working conditions and their effects on employee health and wellbeing. Cochrane Database Syst Rev. 2010;(2):CD008009, http://dx.doi.org/10.1002/14651858.cd008009.pub2.

20. Italian National Institute of Statistics [Internet]. Rome: The Institute; c2005 [cited 2011 May 8]. [Health and use of health care in Italy]. Available from: http://www.istat.it. Italian.

21. Barbadoro P, Cotichelli G, Chiatti C, Simonetti ML, Marigliano A, di Stanislao F, et al. Socio-economic determinants and self-reported depressive symptoms during postpartum period. Women Health. 2012;52(4):352-68, http://dx.doi.org/ 10.1080/03630242.2012.674090.

22. World Health Organization. Obesity, preventing and managing. The global epidemic. Geneva: The Organization; 1998.

23. Craig CL, Marshall AL, Sjostrom M, Bauman AE, Booth M, Ainsworth BE, et al. International Physical Activity Questionnaire: 12 -country reliability and validity. Med Sci Sports Exerc. 2003;35(8):1381-95, http://dx.doi.org/10.1249/01.MSS. 0000078924.61453.FB.

24. Luckhaupt SE, Cohen MA, Li J, Calvert GM. Prevalence of obesity among U.S. workers and associations with occupational factors. Am J Prev Med. 2014 Mar;46(3):237-48, http://dx.doi.org/10.1016/j.amepre.2013.11.002.

25. Eurostat [Internet]. European Commission employment statistics. [updated 2015 Aug; cited 2016 Apr 23]. Available from: http://ec.europa.eu/eurostat/statistics-explained/index. php/Employment_statistic.

26. Kim IH, Muntaner C, Vahid Shahidi F, Vives A, Vanroelen C, Benach J. Welfare states, flexible employment, and health: A critical review. Health Policy. 2012;104(2):99-127, http://dx.doi.org/10.1016/j.healthpol.2011.11.002.

27. Lim SS, Vos T, Flaxman AD, Danaei G, Shibuya K, AdairRohani $\mathrm{H}$, et al. A comparative risk assessment of burden of disease and injury attributable to 67 risk factors and risk factor clusters in 21 regions, 1990-2010: A systematic analysis for the Global Burden of Disease Study 2010. Lancet. 2012;380(9859):2224-60, http://dx.doi.org/10.1016/S0140-67 36(12)61766-8.

28. Park HA, Cho JJ. Economic activities and socioeconomic status of morbidly obese Korean adults. Korean J Obes. 2011;20(4):210-8, http://dx.doi.org/10.7570/kjo. 2011.20.4.210.

29. Rosso GL, Perotto M, Feola M, Bruno G, Caramella M. Investigating obesity among professional drivers: The high risk professional driver study. Am J Ind Med. 2015 Feb;58(2):212-9, http://dx.doi.org/10.1002/ajim.22400.

30. Kivimäki M, Virtanen M, Kawachi I, Pejtersen JH, Pentti J, Rugulies R, et al. Long working hours, socioeconomic status, 
and the risk of incident type 2 diabetes: A meta-analysis of published and unpublished data from 222120 individuals. Lancet Diabetes Endocrinol. 2015 Jan;3(1):27-34, http:// dx.doi.org/10.1016/S2213-8587(14)70178-0.

31. Champagne N, Abreu M, Nobrega S, Goldstein-Gelb M, Montano M, Lopez J, et al. Obesity/overweight and the role of working conditions: A qualitative, participatory investigation [Internet]. Boston (MA): MassCOSH; 2012 [cited 2014 Sep 30]. Available from: http:/drupal.masscosh.org/files/ Obesity\%20and\%20Work\%20Report,\%20Embargoed $\% 20$ until\%2011-13.pdf.

32. Puhl R, Brownell K. Bias, discrimination, and obesity. Obesity Res. 2001;9(12):788-905, http://dx.doi.org/10.1038/ oby.2001.108.

33. Acs Z, Lyles A. Obesity, business, and public policy. Cheltenham: Edward Elgar Publishing; 2007.

34. Neovius K, Johansson K, Rössner S, Neovius M. Disability pension, employment and obesity status: A systematic review. Obes Rev. 2008;9(6):572-81, http://dx.doi.org/10.1111/ j.1467-789X.2008.00502.x.

35. Neovius K, Johansson K, Clark M, Neovius M. Obesity status and sick leave: A systematic review. Obes Rev. 2009;10(1): 17-27, http://dx.doi.org/10.1111/j.1467-789X.2008.00521.x.

36. Lopez-Arana S, Avendano M, van Lenthe FJ, Burdorf A. Trends in overweight among women differ by occupational class: Results from 33 low- and middle-income countries in the period 1992-2009. Int J Obes (Lond). 2013;38(1):97105, http://dx.doi.org/10.1038/ijo.2013.50.

37. Van Duijvenbode DC, Hoozemans MJ, van Poppel MN, Proper KI. The relationship between overweight and obesity, and sick leave: A systematic review. Int J Obes (Lond). 2009;33(8):807-16, http://dx.doi.org/10.1038/ijo.2009.121.

38. Ogle W. Letter to the registrar-general on the mortality in the registration districts of England and Wales during the ten years 1871-1880. Supplement to the 45th annual report of the registrar general of births, deaths and marriages in England. London: Eyre and Spottiswood; 1885.

39. Last J. A dictionary of epidemiology. Oxford: Oxford University Press; 1995.

40. Checkoway H, Pearce N, Kriebel D. Precision and validity in study design. In: Checkoway H, Pearson DC, Kriebel D, editors. Research methods in occupational epidemiology. Oxford: Oxford University Press; 2004. p. 83-121, http://dx.doi. org/10.1093/acprof:oso/9780195092424.001.0001.

41. Lyytikäinen P, Lallukka T, Lahelma E, Rahkonen O. Sleep problems and major weight gain: A follow-up study. Int J Obes (Lond). 2011 Jan;35(1):109-14, http://dx.doi. org/10.1038/ijo.2010.113.

42. Barbadoro P, Santarelli L, Croce N, Bracci M, Vincitorio D, Prospero E, et al. Rotating shift-work as an independent risk factor for overweight Italian workers: A cross-sectional study. PLoS One. 2013 May 10;8(5):e63289, http://dx.doi. org/10.1371/journal.pone.0063289.

43. Pileggi C, Lotito F, Bianco A, Nobile CG, Pavia M. Relationship between chronic short sleep duration and childhood body mass index: A school-based cross-sectional study. PLoS One. 2013 Jun 21;8(6):e66680, http://dx.doi.org/10.1371/ journal.pone. 0066680.

44. World Health Organization [Internet]. Geneva: The Organization; 2014. [updated 2015 Jan; cited 2014 Sep 30]. Obesity and overweight. Available from: http:/www.who.int/mediacentre/factsheets/ss311/en/.

45. Capodaglio P, Castelnuovo G, Brunani A, Vismara L. Functional limitations and occupational issues in obesity: A review. Int J Occup Saf Ergon. 2010;16:507-23.

46. Martin-Moreno JM, Anttila A, von Karsa L, Alfonso-Sanchez JL, Gorgojo L. Cancer screening and health system resilience: Keys to protecting and bolstering preventive services during a financial crisis. Eur J Cancer. 2012;48(14): 2212-8, http://dx.doi.org/10.1016/j.ejca.2012.02.060.

This work is available in Open Access model and licensed under a Creative Commons Attribution-NonCommercial 3.0 Poland License - http://creativecommons.org/ licenses/by-nc/3.0/pl/deed.en. 